\title{
The Contribution of Pharmacological Agents in the History of Organ Transplantation
}

\author{
Yoko Uryuhara and Koji Kawakami* \\ Department of Pharmacoepidemiology, Graduate School of Medicine and Public Health, Kyoto University, Kyoto, Japan
}

\begin{abstract}
More than 200,000 people in the world currently need life-saving organ transplants. Transplantation medicine is the one field of medicine that requires a third party, which is why so much effort is put into ensuring that transplanted organs survive as long as possible. The history of organ transplantation is the story of a battle with immunity, and pharmacological agents have done much to help physicians and patients gain the upper hand in this struggle. This paper provides an overview of the contributions pharmacological agents have made in the history of organ transplantation, with a focus on the field's early history.
\end{abstract}

Keywords: Organ transplantation; Cyclosporine; $\mathrm{T}$ cell signal transduction mechanism; Therapeutic drug monitoring

\section{Introduction}

The need for organ transplants is increasing worldwide. The ongoing lack of available organs has resulted in an increase in the number of patients on waiting lists. In 2012, 120,000 people in the United States (US), 63,800 people in the European Union (EU), and 13,000 people Japan were waiting for organ donations [1-3]. Each day, on average, 18 people in the US and 12 people in the EU die while waiting for a transplant $[1,2]$.

Sculptures and images of creatures possessing elements from multiple beings, such as that seen in the "The Chimaera of Arezzo" which depicted as a lion, with the head of a goat arising from its back, and a tail that ended in a snake's head, are found in countries all over the world. This suggests that organ transplantation has been a dream of the human race since ancient times and the chimera became the starting point of the idea for an organ transplantation study. The men whose research would eventually lead to the realization of that dream were Emerich Ullmann of Austria and Alexis Carrel of France.

\section{Early Transplantation Medicine: The Barrier of Immunity}

Ullmann performed the first successful renal transplant in a dog in 1902 [4]. Carrel researched methods of vascular anastomosis, devising the triangular method still used widely today. In 1906, Carrel performed a renal transplant on a dog using the patching method; the procedure was successful to the extent that urine appeared 30 minutes after surgery and the animal survived for 8 days [5]. Subsequently, he continued his experiments on animals, at one time saying, "From a surgical standpoint the problem of the graft of organs can be considered as having been solved. But, from a biological standpoint, no conclusion has thus far been reached because the interactions of the host and of its new organ are still practically unknown" [6]. This was the beginning of the battle with immunity. The world's first human-to-human organ transplant was performed on April 3, 1933. The Ukrainian surgeon Yu Yu Voronoy took a kidney from a dead person and transplanted it into the thigh of a patient with acute renal failure; the patient died 36 hours later [7]. Although the reason was unclear at the time, Lexer of the University of Jena and Williamson of the Mayo Clinic speculated that some kind of immunological factor was preventing allotransplants from succeeding $[8,9]$.
Hindered by the barrier posed by immunity, other methods were sought to achieve successful allotransplants, and artificial methods of inducing tolerance were attempted. Peter Medawar, a zoology professor at the University of London, discovered "acquired tolerance" [10], and was awarded the 1960 Nobel Prize in Physiology or Medicine for his efforts.

After it was shown that grafts could survive under particular conditions, it was thought that renal transplantation might be possible between monozygotic twins with the same antigens. Joseph Murray, who was awarded the 1990 Nobel Prize in Physiology or Medicine, and his team at Peter Bent Brigham Hospital in Boston in the US performed the world's first renal transplant in identical twins on December 23, 1954. The graft was not rejected, and the recipient survived for 8 years after the operation, becoming the world's first successful case [11].

This success inspired the idea that organs may survive if lymph node function could be suppressed. In 1959 and 1960, a team led by Hamburger of France devised a method by which recipients received full-body X-ray irradiation to reduce the number of leukocytes [12]. However, this technique was never put into practice because of the serious complications it caused. The next round of ideas focused on using pharmacological agents.

Starting at around 1955, David Hume of Murray's team began using cortisone in renal transplants recipients [13], but in 1958, it was discovered that 6-mercaptopurine possesses strong immunosuppressant action [14]. This drug caused severe side effects, but its derivative "azathioprine" caused relatively minor side effects and was shown to be effective as an immunosuppressant agent.

Roy Calne at Cambridge University in the United Kingdom (UK)

*Corresponding author: Koji Kawakami, MD, Phd, Department of Pharmacoepidemiology, Graduate School of Medicine and Public Health, Kyoto University, Yoshida Konoecho, Sakyoku, Kyoto 606-8501, Japan, Tel: +81-75-7534459; Fax: +81-75-753-4469; E-mail: kawakami.koji.4e@kyoto-u.ac.jp

Received November 15, 2013; Accepted December 30, 2013; Published January 02, 2014

Citation: Uryuhara Y, Kawakami K (2014) The Contribution of Pharmacological Agents in the History of Organ Transplantation. Pharm Anal Acta 5: 277. doi: 10.4172/2153-2435.1000277

Copyright: @ 2014 Uryuhara Y, et al. This is an open-access article distributed under the terms of the Creative Commons Attribution License, which permits unrestricted use, distribution, and reproduction in any medium, provided the original author and source are credited. 
confirmed azathioprine's effectiveness in renal transplants in dogs in 1961 [15], and Murray applied it to human renal transplants in 1962 [16]. Four of the first 5 patients survived. In the first case, a 24-year-old man who received a kidney from a deceased donor, the organ survived for more than 1 year, showing allotransplants to be possible when immunity is suppressed with pharmacological agents.

Azathioprine began to be used during transplantation of other organs in humans around the same time. Thomas Starzl of the University of Colorado performed the world's first liver transplant on March 1, 1963 [17]. The patient was a 3-year-old child with biliary atresia. Although the child died immediately after the transplant, Starzl continued performing liver transplants, and in 1967 one of his patients survived for 400 days. Calne performed the first liver transplant in Europe at Addenbrooke's Hospital in the UK in 1968 [18]. Through the efforts and passion of these 2 surgeons, by the end of the 1970s liver transplant surgery, which required highly complex techniques, had nearly been established.

James Hardy at University of Mississippi performed the world's first lung transplant on June 11, 1963. Although the graft functioned immediately after the operation, the patient died 18 days later from renal failure and general debility resulting from an extensive left-lung and thoracic-wall malignancy [19]. Norman Shum way of Stanford University had been performing heart transplants in dogs since the early 1960s, and was researching methods of immunosuppression to achieve the succsess in humans. However, it was Christiaan Barnard who shocked the world when he performed the world's first heart transplant in a human on December 3, 1967, at the Groote Schuur Hospital in Cape Town. The recipient was a 54-year-old man who had experienced repeated myocardial infarctions. He died 18 days after surgery, from pneumonia [20]. In 1968, Barnard attempted a second heart transplant, and this time the patient survived for 9 months [21]. This success ushered in a heart-transplant boom, with about 100 such procedures being performed around the world in 1968. However, ultimately, the patients all died due to organ rejection. Many surgeons had thought transplants would succeed if their surgical skills were good enough, but they soon came to understand the formidable barrier posed by immunity-induced graft rejection.

\section{Dawn of a New Era: The Arrival of "Cyclosporine"}

In 1969, H.P. Frey, a researcher at the Swiss pharmaceutical company Sandoz (now called Novartis) brought back a sample of soil from his holiday at Hardanger Vidda in Norway [22]. This soil would, more than 10 years later, lead to an astounding development in the field of medicine.

Cyclosporine, the metabolite of soil fungi Cylindrocarpon lucidum Booth and Tolypocladium inflatum Gams, is a hydrophobic cyclic polypeptide composed of 11 amino acids with a molecular weight of 1203 [22]. It was purified at Sandoz in 1973 and its structure elucidated after chemical degradation, together with X-ray crystallographic analysis of an iododerivative [23]. It first underwent antibiotic screening at Sandoz, but was abandoned when it failed to show any antifungal activity. However, Jean Borel, a young scientist who had joined Sandoz 3 years earlier, quickly discovered that one of the metabolites isolated from the extract was markedly immunosuppressive. Additionally, the influence of this factor, cyclosporin A (CyA), on both cellular and humoral immune activity had been established in cultured cells. The $\mathrm{ED}_{50}$ was found at about $15 \mathrm{ng} / \mathrm{ml}$, a concentration which is also effective in inhibititing proliferation of mitogen stimulated spleen cells [24]. Borel pushed his research ahead with enthusiasm, despite some opposition within the company. He found that the new agent reversibly inhibited the function of $\mathrm{T}$ lymphocytes and was nontoxic to several types of cell proliferation in a variety of animal species, such as mice (50-300 mg/kg of CyA per oral) [25,26], guinea-pigs $(10-100 \mathrm{mg} / \mathrm{kg}$ of CyA intraperitoneally) [26], and rhesus monkey $(50-250 \mathrm{mg} / \mathrm{kg}$ of CyA intramuscularly) [27].

In 1976, Borel presented his findings at a British Immunology Association meeting [25], which was attended by David White, who worked at Calne's laboratory. Inspired by the presentation, White acquired some CyA and conducted repeated experiments at Calne's laboratory. They demonstrated that CyA prolonged allograft survival of heart transplants in rats [28], renal transplants in dogs [29], and heart transplants in pigs (15 or $25 \mathrm{mg} / \mathrm{kg}$ of CyA intramuscularly) [30].

In 1978, Calne performed the first deceased renal transplant using CyA, and presented his results to the Transplantation Society Congress in Rome [31]. The auditorium was filled to capacity, and his presentation had a huge impact. The following year, he used CyA in a liver transplant patient. Calne mainly used CyA alone, but in 1980, Starzl obtained good results in liver transplants with a combination of CyA and steroids [32]. An analysis of 1,000 liver transplants performed by Starzl showed a 1-year survival rate for liver transplants of $30 \%$ when using azathioprine. This rate soared to $74 \%$ with CyA [33]. In human heart transplantation, CyA was first introduced in December, 1980, and the use of it also resulted in a 1-year survival rate of over $80 \%$ in heart transplants [34].

CyA was approved in Switzerland (as Sandimmun ${ }^{\circledR}$ ) in 1983, and soon came to be used around the globe. As the outcomes of transplants improved, the number of procedures being performed rose steadily, with particularly rapid growth in heart and liver transplants. In response, a National Institutes of Health consensus meeting in June 1983 concluded that the experimental stage for liver transplants was over, and the procedure was a mainstream treatment that should be covered by health insurance.

Currently, several immunosuppressive agents are used in patients undergoing organ transplantation such as steroids, azathioprine, mizoribine, tacrolimus, mycophenolate mofetil, sirolimus, everolimus, basiliximab, daclizumab, muromonab-CD3, and CyA. These agents have been used as combination therapy and have improved patient quality of life. The discovery of CyA broke through the formidable barrier posed by immunity, and led to a dramatic rise in both patient and graft survival rates, establishing transplantation medicine as an everyday form of medical care. CyA was an epoch-making discovery in the field of transplantation medicine, ushering in what has been called the "cyclosporine era".

\section{The Contribution of Immunosuppressants in Elucidating T Cell Signaling}

CyA greatly reduced rejection rates, but the only aspect understood about its mode of action was that it "specifically suppresses helper T cell activity in the resting phase, which suppresses the binding of interleukin-2 and other cytokines".

However, 1984 saw the discovery of the CyA binding protein cyclophilin (CyP), which exists in abundance in the cytoplasm by Handschumacher [35]. Then, in 1989, CyP was shown to be identical to peptidyl-prolyl cis/trans isomerase (PPIase) by Takahashi. PPIase participates in the formation of protein superstructures by promoting the cis/trans isomerization of peptide binding on proline amino terminals inside proteins. It was also discovered that CyA inhibits this enzyme's 
activity [36]. The same year, it was shown that FK binding protein (FKBP) - a binding protein of tacrolimus (common name FK506; manufactured by Fujisawa Pharmaceutical Co., now Astellas Pharma Inc.) - was also identical or PPIase, and that tacrolimus inhibited PPIase activity. PPIase activity is not thought to be directly involved in the immunosuppressant effect, but rather the immunosuppression is thought to be due to CyA-CyP complexes and FK506-FKBP complexes, the target of which is calcineurin [37].

Therefore, CyA inhibits the activation of the calcium calmodulinactivated phosphatase calcineurin via complex formation with CyP. Thereby, it prevents the translocation of the transcription factor known as nuclear factor of activated T cells (NF-AT). CyA also inhibits activation of the transcription factor NF- $\mathrm{KB}$, and $\mathrm{T}$ cell activation is suppressed by inhibition of interleukin-2 gene expression [38-40]

Research such as this into the modes of action of CyA and tacrolimus, which have similar clinical effects, elucidated the $\mathrm{T}$ cell signal transduction mechanism. Both drugs were renamed "calcineurin inhibitors" rather than "immunosuppressants", and both contributed to decode the black box of the immune mechanism.

\section{Contribution to Therapeutic Drug Monitoring}

Therapeutic drug monitoring (TDM) is performed in transplant recipients to help to prevent rejection and avoid side effects. TDM requires determining the dose each patient needs on an individual basis. CyA exhibits its immunosuppressant effect by inhibiting calcineurin inside $\mathrm{T}$ cells. It has been shown that the inhibition of calcineurin activity is greatest 1-2 hours after administration, as expressed by maximum blood concentration [41]. Absorption profiles have been suggested to be particularly important in predicting pharmacological activity. The first formulation of CyA, Sandimmun ${ }^{\mathbb{R}}$ oral solution, used carrier oil as its base, which was emulsified by bile acid after oral administration and absorbed in the upper digestive tract [42]. Therefore, Sandimmun ${ }^{\circledR}$ displayed considerable inter-and intrapatient variability, as its absorption was bile-dependent and affected by concomitant intake of food.

Pharmaceutical research into minimizing this variability led to the development of $\mathrm{Neoral}^{\circledR}$, a microemulsion preconcentrate with a wellbalanced combination of a lipophilic solvent (glycerine fatty acid ester), hydrophilic solvent (propylene glycol), and surfactant (polyoxyethylene hydrogenated castor oil). Dissolving this in water forms an oil/water emulsion, and since its solubility and properties are maintained, it is easily absorbed in the upper digestive tract [40]. As such, it is not greatly affected by food or bile acid, which allows for stable absorption [43].

This stabilized pharmacokinetic profile contributed to an improvement in clinical results and the development of new TDM procedures. Regarding clinical results, a meta-analysis of 5,567 transplant patients drawn from 46 reports showed significantly fewer acute rejections and adverse events with $\mathrm{Neoral}^{\mathbb{R}}$ than with Sandimmun ${ }^{\circledR}$ [44]. Since absorption of Sandimmun ${ }^{\circledR}$ is not stable, its trough level (C0) was measured. For Neoral ${ }^{\circledR}$, Mahalati et al. first tried measuring the absorption profile (AUC0-4), which is important in predicting pharmacological activity. They showed that TDM could optimize the effectiveness and safety of the drug $[45,46]$. Moreover, to further simplify TDM, it was proposed that the concentration 2 hours after administration (C2) be used, because it has the strongest correlation with AUC0-4 [47]. Called C2 monitoring, its clinical usefulness was verified in prospective multicenter studies in renal [48], liver [49], and heart transplant patients [50]. In this way, the pharmacological agents used in transplantation medicine-namely calcineurin inhibitorspromoted the evolution of TDM and helped to realize the concept of individualized therapy.

\section{Conclusion}

Immunosuppressants have been essential to breaking through the barrier posed by immunity in the development of transplantation medicine. They have not only improved clinical results, but also contributed greatly to elucidating the $\mathrm{T}$ cell signal transduction mechanism and achieving advancements in TDM. It would not be an overstatement to say that transplant pharmaceutical therapy has made wide-ranging contributions to the development of medicine. We believe that examining histories, such as in this case, can show us the wisdom, enthusiasm, pioneer spirit, and innovative thinking of our predecessors, and motivate us to tackle as-yet unmet medical needs.

\section{References}

1. United network for organ sharing (2013)

2. European Comission DG Health and Consumers (2013)

3. Japan organ transplant network (2013).

4. Ullman E (1902) Experimentalle Nierentransplantation. Wien klin Wschr 15 281-282.

5. Carrel A, Guthrie C (1906) Anastomosis of blood vessels by the patching method and transplantation of the kidney. JAMA 47: 1648-1651.

6. Carrel A (1910) Remote Results of the Replantation of the kidney and the spleen. J Exp Med 12: 146 -150.

7. Hamilton D, Reid W (1984) Yu. Yu. Voronoy and the first human kidney allograft. Surg Gynecol Obstet 159: 289-294.

8. Lexer E (1914) Free Transplantation. Ann Surg 60: 166-194.

9. Williamson C (1923) Some observations on the length of survival and function of homogenous kidney transplants. Preliminary report. J Urol 10: 275.

10. Billingham R, Brent $L$, Medawar $P$ (1953) Actively acquired tolerance of foreign cells. Nature 172: 603-606.

11. Merrill J, Murray J, Harrison H, Guild W (1956) Successful homotransplantation of the human kidney between identical twins. JAMA 160: 277-282.

12. Hamburger J, Vaysse J, Crosnier J, Auvert J (1962) Renal homotransplantation in man after radiation of the recipient: experience with six patients since 1959 Am J Med 32: 854-871.

13. Hume D, Merrill J, Miller B, Thorn G (1955) Experiences with renal homotransplantation in the human: report of nine cases. J Clin Invest 34: 327382

14. Calne R (1960) The rejection of renal homografts. Inhibition in dogs by 6-mercaptopurine. Lancet 275: 417-418.

15. Calne R (1961) Inhibition of the rejection of renal homografts in dogs by purine analogues. Transplant Bull 28: 65-81.

16. Murray J, Merrill J, Harrison J, Wilson R, Dammin G (1963) Prolonged survival of human-kidney homografts by immunosuppressive drug therapy. $\mathrm{N}$ Engl $J$ Med 268: 1315-1323.

17. Starzl T, Marchioro T, Vonkaulla K, Hermann G, Brittain R, et al. (1963) Homotransplantation of the Liver in Humans. Surg Gynecol Obstet 117: 659676

18. Calne R, Williams R (1968) Liver transplantation in man. I. Observations on technique and organization in five cases. Br Med J 4: 535-540.

19. Hardy J (1999) The first lung transplant in man (1963) and the first heart transplant in man (1964). Transplant Proc 31: 25-29.

20. Barnard C (1967) A human cardiac transplant: An interim report of a successful operation performed at Groote Schuur Hospital, Capetown. S Afr Med J 41 : 1271-1274.

21. Barnard C (1968) Human cardiac transplantation. An evaluation of the first two 
Citation: Uryuhara Y, Kawakami K (2014) The Contribution of Pharmacological Agents in the History of Organ Transplantation. Pharm Anal Acta 5: 277. doi: 10.4172/2153-2435.1000277

operations performed at the Groote Schuur Hospital, Cape Town. Am J Cardiol 22: 584-596.

22. Borel J, Kis Z, Beveridge T (1995) The History of the discovery and development of cyclosporine (Sandimmune ${ }^{\circledR}$ ): The search for anti-inflammatory drugs. The Search for Anti-Inflammatory Drugs 27-63.

23. Petcher T, Weber H, Rüegger A (1976) Crystal and molecular structure of an iodo-derivative of the cyclic undecapeptide cyclosporin A. Helv Chim Acta 59: 1480-1489.

24. Borel J, Wiesinger D (1977) Effect of cyclosporin A on murine lymphoid cells. In Regulatory Mechanisms in Lymphocyte activation. Academic Press, New York: 716-718

25. Borel J, Feurer C, Gubler H, Stähelin H (1976) Biological effects of cyclosporin A: A new antilymphocytic agent. Agents and actions 6: 468-475.

26. Borel J, Feurer C, Magnée C, Stähelin H (1977) Effects of the new antilymphocytic peptide cyclosporin A in animals. Immunology 32: 1017-1025.

27. Borel J (1981) From our laboratories: cyclosporin A. Triangle 20: 97-105.

28. White D, Rolles K, Ottawa T, Turell O (1980) Cyclosporin-A-induced long-term survival of fully incompatible skin and heart grafts in rats. Transplant Proc 12: 261-265

29. Calne R, White D (1977) Cyclosporin A-A powerful immunosuppressant in dogs with renal allografts. IRCS Medical Science: Drug Metabolism and Toxicology 5: 595.

30. Calne R, White D, Rolles K, Smith D, Herbertson B (1978) Prolonged survival of pig orthotopic heart grafts treated with cyclosporin A. Lancet 1: 1183-1185.

31. Calne R, White D, Thiru S, Evans D, McMaster P, et al. (1978) Cyclosporin A in patients receiving renal allografts from cadaver donors. Lancet 2: 1323-1327.

32. Starzl T, Klintmalm G, Porter K, Iwatsuki S, Schröter G (1981) Liver transplantation with use of cyclosporin a and prednisone. N Engl J Med 305: 266-269.

33. Iwatsuki S, Starzl T, Todo S, Gordon R, Esquivel C, et al. (1988) Experience in 1,000 liver transplants under cyclosporine-steroid therapy: a survival report. Transplant Proc 20: 498-504.

34. Oyer P, Stinson E (1983) Cyclosporine in cardiac transplantation: a 2 1/2 year follow-up. Transplant Proc 15: 2456-2452.

35. Handschumacher R, Harding M, Rice J, Drugge R, Speicher D (1984) Cyclophilin: a specific cytosolic binding protein for cyclosporin A. Science 226: 544-547.

36. Takahashi N, Hayano T, Suzuki M (1989) Peptidyl-prolyl cis-trans isomerase is the cyclosporin A-binding protein cyclophilin. Nature 337: 473-475.
37. Liu J, Farmer J Jr, Lane W, Friedman J, Weissman I, et al. (1991) Calcineurin is a common target of cyclophilin-cyclosporin A and FKBP-FK506 complexes. Cell 66: 807-815.

38. Schreiber S, Crabtree G (1992) The mechanism of action of cyclosporin A and FK506. Immunol Today 13: 136-142.

39. Ho S, Clipstone N, Timmermann L, Northrop J, Graef I, et al. (1996) The mechanism of action of cyclosporin A and FK506. Clin Immunol Immunopathol 80: S40-45.

40. Nishi Y (2001) Neoral (Cyclosporin microemulsion preconcentrate): Pharmacokinetics, pharmacodynamics and its improved clinical outcome. Folia Pharmacol Jpn 118: 107-115.

41. Halloran P, Helms L, Kung L, Noujaim J (1999) The temporal profile of calcineurin inhibition by cyclosporine in vivo. Transplantation 68: 1356-1361.

42. Drewe J, Beglinger C, Kissel T (1992) The absorption site of cyclosporin in the human gastrointestinal tract. Br J Clin Pharmacol 33: 39-43.

43. Mueller E, Kovarik J, van Bree J, Grevel J, Lücker P, et al. (1994) Influence of a fat-rich meal on the pharmacokinetics of a new oral formulation of cyclosporine in a crossover comparison with the market formulation. Pharm Res 11: 151155

44. Shah M, Martin J, Schroeder T, First M (1999) The evaluation of the safety and tolerability of two formulations of cyclosporine: neoral and sandimmune. A meta-analysis. Transplantation 67: 1411-1417.

45. Mahalati K, Belitsky P, Sketris I, West K, Panek R (1999) Neoral monitoring by simplified sparse sampling area under the concentration-time curve: its relationship to acute rejection and cyclosporine nephrotoxicity early after kidney transplantation. Transplantation 68: 55-62.

46. Mahalati K, Belitsky P, West K, Kiberd B, Fraser A, et al. (2001) Approaching the therapeutic window for cyclosporine in kidney transplantation: a prospective study. J Am Soc Nephrol 12: 828-833.

47. Barama A, Perner F, Beauregard-Zollinger L, Prestele H (2000) Absorption profiling of cyclosporine therapy for de novo kidney transplantation: a prospective randomized study comparing sparse sampling to trough monitoring Transplantation 69: S162.

48. Stefoni S, Midtved K, Cole E, Thervet E, Cockfield S, et al. (2005) Efficacy and safety outcomes among de novo renal transplant recipients managed by C2 monitoring of cyclosporine A microemulsion: Results of a 12-month, randomized, multicenter study. Transplantation 79: 577-583.

49. Levy G, Burra P, Cavallari A, Duvoux C, Lake J, et al. (2002) Improved clinical outcomes for liver transplant recipients using cyclosporine monitoring based on 2-hr post-dose levels (C2). Transplantation 73: 953-959.

50. Mathias H, Ozalp F, Will M, Borland W, Payne C, et al. (2005) A randomized controlled trial of $\mathrm{C} 0$ - Vs $\mathrm{C} 2$-guided therapeutic drug monitoring of cyclosporine in stable heart transplant patients. J Heart Lung Transplant 24: 2137-2143. 